\title{
Application of Microbes for Recovery of Residual Crude Petroleum
}

\author{
Ishrat Jahan Badruddin ${ }^{1}$, Brajesh Singh ${ }^{1}$, Kritika Pandey ${ }^{1}$, Ashutosh Kumar Pandey ${ }^{1}$, \\ Srinath Pandey ${ }^{2}$, Ved Kumar Mishra ${ }^{2}$ and Prashant Ankur Jain ${ }^{3}$ \\ ${ }^{1}$ Department of Biochemical Engineering, Harcourt Butler Technical University (HBTU), \\ Kanpur- 208002, India \\ ${ }^{2}$ Department of Biotechnology, Naraina Vidya Peeth Engineering and Management Institute, \\ [Affiliated to Dr A P J Abdul Kalam Technical University (AKTU Code-429), Lucknow, Uttar \\ Pradesh, India], Naraina Group of Institution, Gangaganj, Panki, Kanpur, \\ Uttar Pradesh-208020, India \\ ${ }^{3}$ Department of Computational Biology and Bioinformatics, Jacob School of Biotechnology and \\ Bioengineering, Sam Higginbottom University of Agriculture, Technology and Sciences \\ (SHUATS), Allahabad, U.P.-211007, India \\ *Corresponding author
}

\section{A B S T R A C T}

After the three-stage recovery processes employing physical, mechanical and chemical methods fail to recover the remaining crude oil. Biotechnology plays an important role to enhance crude oil recovery from the oil reservoirs so as to solve stagnant petroleum production Microbial enhanced oil recovery (MEOR) is an biotechnologically enhanced

\section{Keywords}

MEOR, Bio

surfactant,

Selective

plugging,

Solvents

Article Info

Accepted:

17 June 2017

Available Online:

10 August 2017 oil recovery process which involves injecting specially selected natural bacteria into the reservoir or stimulating indigenous reservoir microbes to produce certain metabolic events that lead to improvement of oil recovery. This paper reviews the mechanisms of oil release and the use of microbes and their metabolic products to enhance oil recovery. Alteration of oil/rock/water interfacial tensions properties and changes in flow behaviour assist the enhancement of oil recovery. Oil recovery can be improved by injecting gases and solvents or by stimulating their production by reservoir microflora in situ for reservoir repressurization and carbonate rock dissolution. The role of microbial surfactants in oil mobilization and that of biopolymers in oil-depleted zones for selective plugging have been delineated. The uses of solvents and organic acids in MEOR have also been briefly reviewed. Some results of laboratory studies are discussed. However due to accumulated toxic metabolites causing growth inhibition, poor yield of metabolic products of useful microbes and longer incubation time, the MEOR potential has not been fully realized. A complete assessment and evaluation of MEOR from an engineering standpoint based on performance, economics and applicability is required to further improve the efficiency of the process Thus, this review attempts to address the methods of oil recovery, MEOR past and recent trends and its future prospect.

\section{Introduction}

The use of microorganisms to release oil from porous media was first suggested by Beckman in 1926. Between 1926 and 1940, little work was done on this topic. Zobell in 1940 and his research group (1947) performed a systematic laboratory investigation in series. Their result 
initiated the use of microorganisms for application in oil recovery. Zobell's first patent involved Desulfovibrio hydrocarbon clasticus bacterium injection along with oxidized sulphur compounds and carbon source such as Lactose, but field trials were not performed [1]. Zobell in a latter patent introduced the concept of addition of a Clostridium species on a carbohydrate for production of oxygen free hydrogen [2]. The main mechanism explained by Zobell for oil extraction from porous media involved processes like Inorganic carbonates dissolution by bacterial metabolites; decrease in oil viscosity by production of bacterial gases thereby promoting its flow; production of wetting agents or surface-active substances by some bacteria; as well as bacteria having high affinity for solids. Zobell in 1947 described and patented the processes by which microbial products such as acids, gases, cell biomass, solvents, and surfaceactive agents in laboratory tests released oil from sandpack columns. Updegraff in 1954 repeated Zobell's experiment and patented his work in 1957 [3, 4]. His experiments were based on conversion of cheap substrate like molasses into oil recovery agents such as acids, gases, biosurfactants and solvents using underground injected microorganisms. In 1954, the USSR, Kuznetsov carried out the first field test and concluded that bacteria present in oil deposits are capable of destroying oil anaerobically to form gaseous products $\left(\mathrm{CO}_{2}, \mathrm{H}_{2}, \mathrm{CH}_{4}, \mathrm{~N}\right)$ [5]. In 1960s and 1970s European countries such as Hungary, Poland and former Czechoslovakia began their research activity in this field. These countries developed various fields trials which were based on the injection of facultative anaerobic or mixed anaerobic bacteria (Bacillus, Pseudomonas, Mycobacterium, Clostridium, Micrococcus, Arthrobacterium, Peptococcus etc) selected based on their ability to produce high quantities of acids, gases, cell biomass, solvents, surfactants and polymers. Details of such activities are described in Lazar's review papers [6, 7]. At the same time Heinningen et al., suggested a new technology in 1958, Selective Plugging recovery. The idea was based on water flood injection of microbial system based molasses to produce polysaccharide slime in situ for improving oil recovery. Efforts were made to produce Xanthan biopolymers or scleroglucan types viscosifying agents for EOR [8].

The terms IOR and EOR have been used interchangeably at times. IOR is improved oil recovery, it is a general term which involves methods for improving oil recovery by means. Example- operational strategies, such as horizontal wells and infill drilling, improve areal and vertical sweep, causing an increase in oil recovery. EOR, or Enhanced oil recovery on the other hand in concept is more specific, and can be considered as IOR subset. EOR implies an oil saturation reduction below the saturation of residual oil (Sor). Recovery of oils that are nearly immobile or immobile due to high viscosity (sands and heavy oils), or are retained due to capillary forces, can be obtained only by lowering oil saturation below Sor. Chemical floods, miscible processes, and steam based methods are EOR methods and are effective for reducing residual oil saturation [49].

The primary production from an oil well involves the earth's overburden pressure on oil-bearing formation or by pumping. After decline of primary production some wells are converted to injector wells with water flooding or sometimes gas flooding are implemented. Even after secondary product effort reaches its economic limit, 2/3 of the original oil is still left in the ground. To remove the remaining oil, tertiary measures are employed [9]. Tertiary measures involve microbial enhanced oil recovery in the oilbearing formation itself. MEOR uses MOs or 
their metabolic end products for residual oil recovery [10].

\section{Mechanisms of oil release}

\section{Alteration of oil/rock/water interfacial tension properties}

\section{Oil water interfacial tension reduction by microbial surfactants}

Biosurfactant production by microbes in situ is an effective mechanism for enhanced oil recovery. Biosurfactants reduce the interfacial tension between the residual oil saturation and the flowing aqueous phase thereby increasing oil recovery. Residual oil is in the form of globules dispersed within the reservoir pore [27].

For effective increase in oil recovery, the IFT required is evaluated by following equation-

$\mathrm{N}_{\mathrm{ca}}=$ Viscous force $/$ capillary force $=\mathrm{U} \mu / \sigma$

Where, $\mathrm{N}_{\mathrm{ca}}=$ Capillary number, $\mathrm{u}=$ Velocity $(\mathrm{m} / \mathrm{s}), \mu=$ Viscosity (Pa.s), $\sigma=$ Interfacial tension $(\mathrm{N} / \mathrm{m})$

Capillary number is the ratio of viscous force to capillary force. Greater the capillary force, more is the ability to mobilize residual oil.

Surfactants by reducing the interfacial tension, increases the capillary number. The interfacial tension between water and hydrocarbon is in order of 30 to $40 \mathrm{mN} / \mathrm{m}$. Therefore, surfactants should reduce the IFT below $0.4 \mathrm{mN} / \mathrm{m}$ for effective mobilization of residual oil.

\section{Alteration of wettability of microbes formation}

Most of the reservoir rocks are water wet, pore throats trap oil rather than the oil being stuck to the surface. In a reservoir, the bacteria can cause changes in the exposed mineral surfaces by various mechanisms-

\section{Attachment of bacteria directly to the surface}

The contact angle is due to homogenous mixtures of mineral and properties of bacterial surfaces. Less uniformity of the surface increases the contact angle, unless the entire mineral surface is colonized by bacteria.

\section{Bacterial metabolites adsorption to mineral surfaces}

Bacterial products such as surfactants adsorb to the mineral surface and by increasing or decreasing the surface hydrophobicity, they have the ability to alter the wettability. This mechanism can be operated at pore diameter.

\section{Mineral coating with exopolysaccharide or biopolymers}

This method is similar to attachment of bacteria directly to the surface. This mechanism is closely related to cell attachment as polymers are associated to cells [26].

\section{Interfacial rheology and its impact on oil} displacement

Bacteria can alter the interfacial properties by adhering to the oil-water interface [11].

The bacteria do not change the interfacial tension, but they alter the elasticity and viscosity of the interface [13].

Interfacial tension is the force required at equilibrium to change interface area whereas elasticity is the response of interface to the dynamic changes. 
Production of bacterial layers at oil-water interface can reduce the oil recovery rate by retarding oil mobility in the formation.

\section{Changes in flow behaviour}

\section{Plugging in high- permeability zones}

If the variations of permeability are a serious problem, this mechanism is highly useful mechanism. Bacterial cells can block pores directly or by producing extracellular slimes.

EPS producing microorganisms are introduced into the formation for pore clogging from where the preferential flow can take place, to enforce other pathways, up to now not used in order to open and allow the oil extraction.

Ultra micro-cells are optimally suited for oil extraction as they can enter into small pores because of their reduced diameter (below $0.2 \mu \mathrm{m}$ ), and by initiating to grow clog these consequently and efficiently divert their flow.

Bacteria can penetrate along high permeability zones and fractures over long distances [56]. The sweep efficiency of water can be improved by inducing biological products along these high permeability channels.

\section{Increase in permeability by production of} organic acids

Many bacteria produce acids under anaerobic condition. Numerous reservoir rocks consist entirely or partly of carbonate.

Bacterial action result in dissolution of carbonate of reservoir rock and visible changes to the naked eyes in calcite and dolomite ores of bacterial action can be produced. Acids Production result in pore enlargement which is favourable where the vital region has become partly plugged instantly round the injection well.

\section{Limitations}

Acids release fine particles that might sweep into the bore throats resulting in plugging which is dangerous

Massive amounts of substrate and acids would be required for extensive dissolution of carbonate rock that is pure.

\section{Gases solution in oil resulting in swelling and decreased viscosity}

Viscosity effects oil displacement. Sulfate reducing bacteria, Desulfovibrio halohydrocarbonoclasticus, $\quad D$. hydrocarbonoclasticus, for oil bearing formation treatment release oil by various mechanisms.

Bacteria utilize crude oil hydrocarbons for production of acids and $\mathrm{CO}_{2}$ [41]. The acids when react with rock carbonates increases permeability and produce more $\mathrm{CO}_{2} \cdot \mathrm{CO}_{2}$ and other gases increase reservoir pressure and dissolve in oil forcing it to swell, increase its volume and reduce viscosity thus resulting displacement.

An increase in volume to a sufficient magnitude might free some of the oil from the ganglia and this effect on oil viscosity may be useful.

$\mathrm{ROIP}=\mathrm{E}_{\mathrm{d}} \mathrm{E}_{\mathrm{v}}$ OOIP

Where, $\mathrm{ROIP}=$ Recoverable oil in place from water flooding, $\mathrm{E}_{\mathrm{d}}=$ displacement efficiency, $\mathrm{E}_{\mathrm{v}}=$ macroscopic sweep efficiency, OOIP = original oil in place

The amount of gas dissolving in oil is given as 
$\Delta \mathrm{SGIP} / \mathrm{OOIP}=\mathrm{R}_{\mathrm{s}}\left(\mathrm{P}_{\mathrm{r}}\right)-\mathrm{R}_{\mathrm{s}}\left(\mathrm{P}_{\mathrm{b}}\right)$

Where, $\Delta \mathrm{SGIP}=$ Solution gas oil in place, $\mathrm{R}_{\mathrm{s}}$ $=$ Solution gas-oil ratio, $\mathrm{P}_{\mathrm{r}}=$ Reservoir pressure, $\mathrm{P}_{b}=$ Original bubble point pressure.

Aerogens, E. coli, Aerobacter, and members of Bacillus and Clostridium are Sulfate reducing bacteria. Other types of microorganisms also produce significant enhancement in oil release when supplied with mineral, nutrients and carbohydrates.

Repressurization by $\mathrm{CH}_{4}, \mathrm{~N}_{2}, \mathrm{CO}_{2}, \mathrm{H}_{2}$ Production

Clostridium acetobutylicum in the absence of gas phase could generate up to $8.8 \mathrm{MPa}$ pressure in laboratory culture mostly due to production of $\mathrm{H}_{2} \cdot \mathrm{H}_{2}$ has very low solubility in water. Rock carbonate generates $\mathrm{CO}_{2}$ which could contribute to this mechanism.

\section{Oil dissolution by solvents, e.g. ketones and} alcohols

Production of appropriate substances in high concentrations to dissolve oil seems unlikely but they can act as co-surfactants by modifying the surfactant behaviour itself. Butanol, microbial generated liquid solvent, partitions between the oil and water phases. The oil viscosity is reduced and mobility is increased due to the presence of solvent portion that dissolves in the oil.

\section{Methods of oil recovery [49]}

\section{Thermal method of oil recovery [15]}

In this method, oil is displaced from the reservoir by a fluid which is assumed to be immiscible and incompressible with the oil. The method makes use of water for displacing oil. The method of gas displacing oil which is saturated with gas at a constant pressure is also considered as displacement by an immiscible fluid. The reason for this is that if the pressure is fixed, gas concentration in the oil never changes. Consequently, additional free gas remains undissolved in the oil, and acts essentially as an immiscible phase [12].

\section{Hot water flood recovery}

Hot water drives improved oil recovery by thermal expansion and viscosity reduction of the oil. Primol expands approximately 5 per cent upon heating from room temperature to $212^{\circ} \mathrm{F}$, and about 10 per cent upon heating from room temperature to $325^{\circ} \mathrm{F}$. These values, when applied to the residual oil recovery using water flooding showed that an additional $3 \%$ oil recovery by swelling or expansion at $212^{\circ} \mathrm{F}$, and $5 \%$ at $325^{\circ} \mathrm{F}$. Hot water flooding is preferred mostly for viscous oils because the ratio of water-oil viscosity at elevated temperature is significantly reduced as compared to ordinary water flood. Barnes injected viscous water slug into a reservoir which had been partially invaded by bottom water [16].

\section{Steam-drive recovery}

Hot water flooding is effectively a steam drive part. Steam injection shows better recovery than other mechanisms. Steam shows an evident effect on thermal swelling and viscosity reduction than with hot water for oil recovery because the steam heating value for pore volume is 4 to 5 times greater than equivalent hot water volume.

\section{Steam distillation}

Steam distillation is the vaporisation of fraction of residual oil left by the hotcondensate water flooding. The oil distillable portions are light components possessing high vapour pressure in comparison with the heavy 
ends. The mixture of oil vapour and steam resulting from distillation is pushed forward until a cooler portion of rock is encountered; both the water vapour and oil are condensed. Due to Steam having higher heat content per unit mass than hot water at the same temperature, high temperature and pressure saturated steam is more effective for oil recovery than low-pressure.

Steam injection results in greater recovery of crude oil than hot water flooding because solvent-extraction, steam distillation and related gas-drive effects are added to swelling and viscosity reduction as recovery mechanisms. Low-gravity crude oils of appreciable amounts are also steamdistillable. Steam distillation is effective for high-gravity crudes resulting in high recovery.

\section{Chemical methods of oil recovery}

A chemical method $[17,28]$ utilizes chemical formulation for displacing fluid, which promotes mobility ratio reduction and/or increase in the capillary number.

\section{Surfactant Flooding}

Surfactants lower the interfacial tension between water and oil. Commercial surfactants or Petroleum sulfonates are often used.

A slug of aqueous surfactant is followed by polymer slug, and then the two chemical slugs are moved along using brine. However, surfactant flooding was largely ineffective method in the past, mainly due to extreme surfactant loss to the porous medium. Reactions of surfactant adsorption with the rock minerals were severe in some cases [14, 15]. Emulsions Treatment and disposal were also of concern.

\section{Alkaline flooding}

In alkaline flooding, IFT reduction is the main mechanism. Aqueous solution of an alkaline chemical, such as carbonate, orthosilicate of sodium, hydroxide is injected in slug form. The alkaline chemical reacts with the crude oil acid components producing surfactant in situ. Spontaneous emulsification may also take place. Depending on the type of emulsion formed, drop entrapment or Drop entrainment may occur which may diminish or enhance the recovery. Alkalis can alter wettability, however, large concentration of alkalis are required for alterations [50]. Due to the various reactions taking place between alkaline chemical and reservoir rock and fluids the process is complex to design

\section{Micellar flooding}

Micellar flooding [33, 32] is a successful chemical method of oil recovery as compared to other chemical flooding processes. The major components of this method are microemulsion slug (or micellar slug) and a polymer slug. These two slugs are driven with the help of brine. Microemulsions are surfactant-stabilized; dispersions of oil-water with small drop size distributions of $10^{-4}$ to $10^{-6} \mathrm{~mm}$.

Microemulsions are miscible with reservoir oil as well as water. Both the chemical slugs are designed in such a way so as to prevail favourable mobility ratio and ultra-low IFT (10-2 $\mathrm{mN} / \mathrm{m}$ or lower) during most part of the displacement. Micellar flooding has been tested in 45 field projects, and has proven to be successful in banking and residual oil production which is left after waterflood. Recovery factors in field projects ranged between 35-50\% OIP. However, economics were unattractive due to high initial expense, high chemicals cost, requirement of small well spacing, and considerable delay in 
response. Moreover, the conditions and geology in many candidate reservoirs (high temperature, clay content and salinity) are inappropriate for application of micellar flooding.

\section{ASP flooding}

Alkaline-Surfactant-Polymer flooding [29, 30] is relatively a new method and is being evaluated by performing various laboratory investigations and field tests. The method utilizes mostly three chemical formulations polymer, alkali and surfactant solutions. The chemical slugs are injected in sequence or as premixed single slug. The major mechanisms are mobility ratio improvement and IFT reduction. Recovery factors in field projects ranged between $25-30 \%$ OIP. The method has been successful for banking and producing residual oil. The mechanisms of ASP are not fully understood however this process holds the potential. Economics are marginal at best.

\section{Gas flooding with dilute surfactant solutions}

Dilute surfactant gas and solution are being used to displace and recover hydrocarbon solution from a subterranean reservoir by using surfactant-enhanced gas flooding. This can be applied to operations of gas flooding where instead of aqueous fluid such as brine or water.

About a third of the hydrocarbons can be recovered using water. The water displaces most of the oil due to a combination of permeability variations, fluid mobility differences and natural fractures.

Oil trapping at small pore throats due to capillary forces also reduces recover. Example: when the oil saturation is above the residual oil saturation.

\section{Polymer flooding}

Water soluble polymers, such as polyacrylamides and polysaccharides are effective in improving mobility ratio and reducing permeability contrast. In most cases, polymer flooding [31] is applied as a slug process (20-40\% PV) and is driven using dilute brine. Polymer concentration is between 200-2000 ppm. The major limitations of polymer flooding are polymer degradation, loss of polymer to the porous medium, and in certain cases, loss of injectivity. In the past, polymer floods were applied too late in the waterflood, when the mobile oil saturation was low; this was the main reason for failure of polymer flood. The effectiveness of this process can be improved by applying polymer flood earlier during waterflood, for example, when the residual oil saturation is below the oil saturation.

Other methods tested include foam, emulsion and the microbial use, but their effect has been insignificant on EOR production thus far.

\section{Methods of oil recovery in MEOR}

\section{Use of biosurfactants in MEOR}

Biosurfactants are a varied group of surface active chemical compounds that are produced by a large variety of microorganisms such as Bacillus sp. [34]. Biosurfactants are able to partition at the water/oil or water/air interfaces due to the presence of both polar and non-polar domains and thus lower the interfacial of surface tension [35]. These surface active biological compounds have several advantages over the chemical surfactant such as higher degradability, higher foaming, lower toxicity and better environmental compatibility, higher selectivity and specific activity at extreme salinity, $\mathrm{pH}$ and temperature [48]. Some 
biosurfactants can reduce heavy oil viscosity as much as by $95 \%$. In addition, by changing the reservoir rock wettability, surfactants can alter the rock to oil relative permeability and thereby increase oil recovery.

Several strategies have been employed when using biosurfactants in MEOR [24]. Injecting biosurfactants producing microorganisms into the reservoir with subsequent propagation through the reservoir rock [25].

Injecting selected nutrients into the reservoir. This stimulates the growth of indigenous MOs that produce biosurfactants.

Ex situ biosurfactant production in bioreactors and subsequent injection in the reservoir.

\section{Use of Bacillus and Clostridium in MEOR}

Microorganisms most commonly used for MEOR processes are species of Clostridium and Bacillus. Microorganisms reduce oil/water interfacial tension (1FT) by producing surfactants and cause emulsification. Several types of surfactants are certain types of lipids and anionic surfactants such as carboxylic acids (fatty acids) [38]. Cooper et al., isolated from the anaerobe Clostridium pasteurumum, neutral lipid biosurfactant and from Bacillus and other Clostridium species, anaerobic biosurfactants [39]. Under anaerobic conditions Bacillus licheniformis also produces surfactant [40]. These species due to their ability for spore production have a greater potential for survival in petroleum reservoirs. Spores are dormant, cells of resistant form that can survive more stressful environmental conditions. Clostridium species produce alcohols, surfactants, solvents and gases, while Bacillus species produce acids, surfactants, polymers and some gases. In sandstone rocks with carbonaceous cementation or carbonate formations, acidproducing microorganisms increase permeability thereby improving oil recovery (Tables 1 and 2).

Table.1 Products and activities of microorganisms potentially useful for enhanced oil recovery or improved production

\begin{tabular}{|l|l|l|}
\hline Product or activity & Examples & Production \\
\hline Gases & $\mathrm{CO}_{2}$ and $\mathrm{CH}_{4}$ & Reservoir repressurization, oil viscosity reduction \\
\hline Acids & Acetic, butyric, lactic & $\begin{array}{l}\text { Formation damage, poor drainage, increase in carbonate } \\
\text { porosity }\end{array}$ \\
\hline Solvents & Ethanol, Acetone, Butanol & Oil viscosity reduction, wettability alteration \\
\hline Polymers & Polysaccharides, Proteins & Mobility control, permeability rectification \\
\hline Bio emulsifiers & $\begin{array}{l}\text { Heteropoly } \\
\text { saccharides, Proteins }\end{array}$ & Oil emulsification, wax and paraffin control \\
\hline $\begin{array}{l}\text { Hydrocarbon } \\
\text { metabolism }\end{array}$ & Anaerobic & $\begin{array}{l}\text { Paraffin control, viscosity alteration, methane } \\
\text { production }\end{array}$ \\
\hline Biomass formation & Microbial cells & Selective plugging \\
\hline Biosurfactants & Glycolipids, Lipopeptides & $\begin{array}{l}\text { Interfacial tension reduction, emulsification, wettability } \\
\text { alteration }\end{array}$ \\
\hline
\end{tabular}


Table.2 Microbial consortia and their metabolites with applications in MEOR [44]

\begin{tabular}{|l|l|l|}
\hline Microbial product & Example microbes & Application in MEOR \\
\hline Biomass & Bacillus, Leucinostoc, Xanthomonas & $\begin{array}{l}\text { Selective plugging and wettability } \\
\text { alteration }\end{array}$ \\
\hline Surfactants & $\begin{array}{l}\text { Acinetobacter, Arthrobacter, Bacillus, } \\
\text { Pseudomonas }\end{array}$ & $\begin{array}{l}\text { Emulsification and de-emulsification } \\
\text { through reduction of IFT }\end{array}$ \\
\hline Polymers & $\begin{array}{l}\text { Bacillus, Brevibacterium, Leuconostoc, } \\
\text { Xanthomonas }\end{array}$ & $\begin{array}{l}\text { Injectivity profile and viscosity } \\
\text { modification, selective plugging }\end{array}$ \\
\hline Solvents & Clostridium, Zymomonas, Klebsiella & $\begin{array}{l}\text { Rock dissolution for better } \\
\text { permeability, oil viscosity reduction }\end{array}$ \\
\hline Acids & Clostridium, Zymomonas, mixed acidogens & Permeability increase, emulsification \\
\hline Gases & $\begin{array}{l}\text { Clostridium, Enterobacter, } \\
\text { Methanobacterium }\end{array}$ & $\begin{array}{l}\text { Increased pressure, oil swelling, IFT } \\
\text { and viscosity reduction }\end{array}$ \\
\hline
\end{tabular}

Table.3 A classification of different microbial reservoir treatments [18] [46] [45]

\begin{tabular}{|l|l|l|}
\hline MEOR process & Microorganism used & Production problem \\
\hline Well stimulation & $\begin{array}{l}\text { Generally surfactant, gas, acid, and } \\
\text { alcohol producers }\end{array}$ & $\begin{array}{l}\text { Low oil relative permeability } \\
\text { Formation damage }\end{array}$ \\
\hline Waterflooding & $\begin{array}{l}\text { Generally surfactant, gas, acid, and } \\
\text { alcohol producers }\end{array}$ & Trapped oil due to capillary forces \\
\hline Permeability modification & $\begin{array}{l}\text { Microorganisms that produce polymer } \\
\text { and/or copious amounts of biomass }\end{array}$ & Poor sweep efficiency Channelling \\
\hline Wellbore cleanup & $\begin{array}{l}\text { Microorganisms that produce } \\
\text { emulsifiers, surfactants and acids. } \\
\text { Microorganisms that degrade } \\
\text { hydrocarbons }\end{array}$ & Paraffin problems Scaling \\
\hline Polymer flooding & Polymer producers & $\begin{array}{l}\text { Unfavourable mobility ratio } \\
\text { Low sweep efficiency }\end{array}$ \\
\hline
\end{tabular}

\section{Other methods of oil recovery}

Other methods of oil recovery using microbes includes introducing denitrifying microorganisms- denitrifying Thiobacilli, such as $T$. denitrificans into an underground rock formation containing carbonate that defines an anaerobic environment, a source of nitrate ion and water,. These microorganisms are involved in nitrate reduction and sulfuric acid production which dissolves the rock formation thereby releasing oil [36].Three bacterial species able to transport in highly permeable porous rocks-Pseudomonas putida, Bacillus subtilis and Clostridium acetobutylicum are potentially applicable in MEOR processes. In addition to their ability to resistance adverse environments, spores of clostridia are strongly suggested for use in MEOR processes as they are the easiest to push through porous rocks [37]. The most largely practiced MEOR technique is by treating producing wells by cyclic stimulation. Using single-well stimulation treatments, improvement of oil production can be done by removing paraffinic or asphaltic deposits from the region near wellbore or from residual oil mobilization in the limited volume of the reservoir that is being treated. Single-well stimulation treatments are practiced because they are relatively inexpensive and with minor modifications they can be implemented to existing field facilities. An alternative method is to improve oil recovery by applying microbes in an ongoing water flood [47]. 
Microbial growth and polymer production have shown improvement in sweep efficiency by permeability modification [45]. Another application of MEOR is fluid diversion. Some microbes preferentially improve sweep efficiency in situ by plugging highpermeability streaks in reservoirs [42] (Table $3)$.

\section{Strategies and factors affecting MEOR}

Some of the mechanisms by which oil recovery efficiency is increased by microbial agents are: Permeability changes, Interfacial tension (IFT) reduction, gas production and wettability alteration [19] [20]. Wettability is defined as "the ability of one fluid to adhere or spread on a solid surface in the existence of other immiscible fluids" [21]. The wettability of rock/fluid systems is a major factor controlling the fluids flow, location and distribution in porous media [22]. The appropriate remedy for oil reservoir depends on the conditions present. Pressure, temperature, $\mathrm{pH}$, salinity, porosity, reservoir geologic make-up, presence of indigenous flora, nutrients availability should also be considered. In situ MEOR involves microorganisms multiple effects on environment and oil. These mechanisms include; acid production, gas formation and increase in pressure, degradation of limestone matrices, oil viscosity reduction and reduction in interfacial tension by biosurfactants, plugging by polymer formation or biomass accumulation, solvent production and also decrease in viscosity which is due to degradation of big organic molecules in oils [22] [23].

\section{Potential advantages of MEOR}

\section{Advantages of MEOR over EOR systems}

It is cheap because the main raw material used mainly is a source of inexpensive carbohydrate source such as molasses with or without organic nutrients.

MEOR is more effective than other EOR operations because the active material is generated throughout the reservoir and during migration their effectiveness would not produce adsorption to the site of action.

In MEOR, the bacteria by diffusing out of the fluid flow main lines can mobilise oil in regions which are not accessible by other methods.

Advantages and Constraints of MEOR Technology [43]

\section{Advantages}

Economically attractive for marginal producing fields.

Easily applied with typical surface equipment for water flooding.

Microbial activity can be stopped by discontinuing injection of nutrients.

Can be applied to wide range of crude oils (i.e. heavy and light oils). Microbes can be selected and adapted for specific reservoir conditions.

Cost of microbial injection fluid is relatively low and is not dependent on the price of crude oil.

\section{Constraints}

Cannot usually be applied in reservoirs having high temperatures (i.e. $>160^{\circ} \mathrm{F}$ ) or salinities (i.e. $>10 \%$ ).

Certain heavy metal ions, which are sometimes contaminants in nutrients, can be toxic to microbes. 
Requires laboratory compatibility testing and proper engineering design.

Mechanisms of oil recovery are still not fully established.

Procedures for optimizing microbes for specific reservoir applications are still in a developmental stage.

Screening criteria for field applications need to be improved.

Reservoir simulators that can reliably predict field performance have not yet been developed.

\section{Future prospects}

A variety of products are produced by microorganisms that are potentially useful for oil recovery. However, this potential is not always realized in actual field trials. Paraffin deposition control; in and around the well bore by microbial processes have had the greatest commercial success. However, the mechanism of these products for improved oil recovery is not known and may be the reason for variable technical performance by these products. MEOR can gain widespread application only when the mechanisms of oil recovery by microbial processes are thoroughly understood and above quantitative measures of microbial performance are obtained. Biosurfactants generating very low interfacial tensions against the crude oil are required for significant improvements in microscopic displacement efficiency in the reservoir. Identifying changes in community structure that occur in response to specific manipulations, for example, nutrients injection and/or exogenous microorganisms, water flooding or during various stages of production is another promising area of research. Various molecular approaches such as restriction fragment length polymorphism (RFLP), temperature or differential gradient gel electrophoresis (TGGE or DGGE), internal transcribed spacer (ITS) amplification, could be used to monitor microbial community composition changes. MEOR is an eco-friendly petroleum recovery process employing resources and techniques of biotechnology that can be used to replace and expand the traditional EOR processes. It has been observed that despite of microbial processes holding great prospect for EOR, the implementation of MEOR remains retarded due to low ultimate oil recovery factor and inconsistency in in situ performance. In situ application of aerobic and anaerobic bacteria in simulated oil reservoir conditions, attached with the stimulation of indigenous microflora have resulted in successful enhancement of both the ultimate oil recovery factor and oil productivity. However, process efficiency can be improved by having a better understanding of the processes and mechanisms in MEOR from an engineering standpoint based on performance, applicability and economics. Advanced MEOR technologies based on the use of some specific enzymes and genetically engineered organisms may prove to be effective and successful in the future. Nevertheless, due to the impending energy crisis an urge in developing novel MEOR seem to be imminent, mainly due to costeffective solution of MEOR over conventional EOR strategies.

\section{Acknowledgement}

I express deepest sense of gratitude towards Dr. Brajesh Singh, having him by my side encouraging me to accomplish this herculean task. He boosted me to ink this article helped me focussing on scripting future prospects pertaining to due proposition.

\section{References}

1. Zobell, C. E. (1946). Action of microörganisms on 
hydrocarbons. Bacteriological

reviews, 10(1-2), 1.

2. Zobell, C. E. (1953). U.S. Patent No. 2,641,566. Washington, DC: U.S. Patent and Trademark Office.

3. Updegraff, D. M., and Wren, G. B. (1954). The release of oil from petroleum-bearing materials by sulfatereducing bacteria. Applied microbiology, 2(6), 309.

4. Davis, J. B., and Updegraff, D. M. (1954). Microbiology in the petroleum industry. Bacteriological reviews, 18(4), 215.

5. Yarbrough, H. F., and Coty, V. F. (1983). Microbially enhanced oil recovery from the upper cretaceous nacatoch formation, Union County, Arkansas. In Proceedings of 1982 Int. Conf. on Microbial Enhancement of Oil Recovery, Ed. by Donaldson and Zajic Published by Bill Linvill, Chief, Technology Transfer Branch, Bartlesville, OK (pp. 149-153)..

6. Lazar, I. I. (1991). Microbial Enhancement of Oil Recovery-Recent Advances. In Proceedings of the 1990 International Conference on Microbial Enhanced Oil Recovery (pp. 485-530). Elsevier.

7. Lazar, I. (1998). International MEOR applications for marginal wells. Pakistan Journal of Hydrocarbon Research, 10(6), 11-30.

8. Hitzman, D. O. (1988). Review of microbial enhanced oil recovery field tests. Proceedings of the Applications of Microorganisms to Petroleum Technology.

9. Morkes, J. (1993). Oil-spills-whose technology will clean up. $R$ and $D$ MAGAZINE, 35(12), 54-56.

10. Singer, M. E., and Finnerty, W. R. (1984). Microbial metabolism of straight-chain and branched alkanes.

11. Bubela, B. (1987). A comparison of strategies for enhanced oil recovery using in situ and ex situ produced biosurfactants. Surfactant Science Series, 25, 143-161.

12. Welge, H. J. (1952). A simplified method for computing oil recovery by gas or water drive. Journal of Petroleum Technology, 4(04), 91-98.

13. Beeder, J., Nilsen, R. K., Thorstenson, T., and Torsvik, T. (1996). Penetration of Sulfate Reducers through a Porous North Sea Oil Reservoir. Applied and environmental microbiology,62(9), 3551-3553.

14. Somasundaran, P., and Hanna, H. S. (1979). Adsorption of sulfonates on reservoir rocks. Society of Petroleum Engineers Journal, 19(04), 221-232.

15. Krumrine, P. H., and Falcone Jr, J. S. (1983, January). Surfactant, polymer, and alkali interactions in chemical flooding processes. In SPE Oilfield and Geothermal Chemistry Symposium. Society of Petroleum Engineers.

16. Barnes, A. L. (1962). The use of a viscous slug to improve waterflood efficiency in a reservoir partially invaded by bottom water. Journal of Petroleum Technology, 14(10), 1-147.

17. Thomas, S., and Ali, S. F. (1999). Status and assessment of chemical oil recovery methods. Energy sources, 21(1-2), 177189.

18. Bryant, R. S., and Lindsey, R. P. (1996, January). World-wide applications of microbial technology for improving oil recovery. In SPE/DOE Improved Oil Recovery Symposium. Society of Petroleum Engineers.

19. Karimi, M., Mahmoodi, M., Niazi, A., AlWahaibi, Y., and Ayatollahi, S. (2012). Investigating wettability alteration during MEOR process, a micro/macro scale analysis. Colloids and Surfaces B: Biointerfaces, 95, 129136. 
20. Sen, R. (2008). Biotechnology in petroleum recovery: the microbial EOR. Progress in energy and combustion Science, 34(6), 714-724.

21. Andersen, M. A., Thomas, D. C., and Teeters, D. C. (1988, January). A New Formation Wettability Test: The Dynamic Wilhelmy Plate Wettability Technique. In SPE Enhanced Oil Recovery Symposium. Society of Petroleum Engineers.

22. Anderson, W. G. (1987). Wettability literature survey-part 6: the effects of wettability on waterflooding. Journal of Petroleum Technology, 39(12), 1-605.

22. Jack, T. R. (1988). Microbially enhanced oil recovery. BIORECOVERY, 1(1), 5973.

23. Khire, J. M., and Khan, M. I. (1994). Microbially enhanced oil recovery (MEOR). Part 1. Importance and mechanism of MEOR. Enzyme and microbial technology, 16(2), 170-172.

24. Shennan, J. L., and Levi, J. D. (1987). In situ microbial enhanced oil recovery. Biosurfactants and biotechnology, 25, 163-181.

25. Bubela, B. (1985). Effect of biological activity on the movement of fluids through porous rocks and sediments and its application to enhanced oil recovery. Geomicrobiology Journal, 4(3), 313-327.

26. Wanger, G., Southam, G., and Onstott, T. C. (2006). Structural and chemical characterization of a natural fracture surface from 2.8 kilometers below land surface: Biofilms in the deep subsurface. Geomicrobiology

Journal, 23(6), 443-452.

27. Willhite, G. P., Green, D. W., and Paul, G. (1998). Enhanced Oil Recovery. SPE Textbook series, 6, 302-308.

28. Thomas, S., and Farouq Ali, S. M. (1993). Field experience with chemical oil recovery methods. In Process
Industries Power the Pacific Rim: Sixth Conference of the Asia Pacific Confederation of Chemical Engineering; Twenty-first Australasian Chemical Engineering Conference; Official Proceedings of Combined Conference 1993 (p. 45). Institution of Engineers, Australia.

29. Jenneman, G. E., Knapp, R. M., McInerney, M. J., Menzie, D. E., and Revus, D. E. (1984). Experimental studies of in-situ microbial enhanced oil recovery. Society of Petroleum Engineers Journal, 24(01), 33-37.

30. Vassoyevich, N. B., Korchagina, Y. I., Lopatin, N. V., and Chernyshev, V. V. (1970). Principal phase of oil formation. International Geology Review, 12(11), 1276-1296.

31. Chang, H. L. (1978). Polymer flooding technology yesterday, today, and tomorrow. Journal of Petroleum Technology, 30(08), 1-113.

32. Thomas, S., Ali, S. M., and Daharu, R. (1986, January). Tertiary recovery of two Alberta oils by micellar flooding. In Annual Technical Meeting. Petroleum Society of Canada.

33. Gogarty, W. B., and Tosch, W. C. (1968). Miscible-type waterflooding: oil recovery with micellar solutions. Journal of Petroleum Technology, 20(12), 1-407.

34. Cooper, D. G., and Goldenberg, B. G. (1987). Surface-active agents from two Bacillus species. Applied and environmental microbiology, 53(2), 224-229.

35. Youssef, N. H., Duncan, K. E., Nagle, D. P., Savage, K. N., Knapp, R. M., and McInerney, M. J. (2004). Comparison of methods to detect biosurfactant production by diverse microorganisms. Journal of microbiological methods, 56(3), 339347. 
36. Sperl, G. T., and Sperl, P. L. (1991). U.S. Patent No. 5,044,435. Washington, DC: U.S. Patent and Trademark Office.

37. Jang, L. K., Chang, P. W., Findley, J. E., and Yen, T. F. (1983). Selection of bacteria with favorable transport properties through porous rock for the application of microbial-enhanced oil recovery. Applied and environmental microbiology, 46(5), 1066-1072.

38. Cooper, D. G., and Zajic, J. E. (1980). Surface-active compounds from microorganisms. Advances in Applied Microbiology, 26, 229-253.

39. Cooper, D. G., Zajic, J. E., Gerson, D. F., and Manninen, K. I. (1980). Isolation and identification of biosurfactants produced during anaerobic growth of Clostridium pasteurianum. Journal of fermentation technology, 58(1), 83-86.

40. Jenneman, G. E., McInerney, M. J., Knapp, R. M., Clark, J. B., Feero, J. M., Revus, D. E., and Menzie, D. E. (1983). Halotolerant, biosurfactantproducing Bacillus species potentially useful for enhanced oil recovery. Dev. Ind.

Microbiol.;(United

States), 24(CONF-8208164-).

41. Premuzic, E. T., and Lin, M. S. (1991). Ch. R-18 Prospects for Thermophilic Microorganisms in Microbial Enhanced Oil Recovery (MEOR). Developments in Petroleum Science, 31, 277-296.

42. Knapp, R. (1983). The use of microorganisms in enhanced oil recovery. Bartlesville Energy Technology Center.
43. Bryant, R. S., and Burchfield, T. E. (1989). Review of microbial technology for improving oil recovery. SPE Reservoir Engineering, 4(02), 151-154.

44. Bryant, R. S., and Burchfield, T. E. (1989). Review of microbial technology for improving oil recovery. SPE Reservoir Engineering, 4(02), 151-154.

45. Raiders, Richard A. Oil recovery and sweep efficiency improvement in parallel core systems due to the metabolism of indigenous microorganisms. 1986.

46. Knapp, R. (1983). The use of microorganisms in enhanced oil recovery. Bartlesville Energy Technology Center.

47. Bryant, R. S., Burchfield, T. E., Dennis, D. M., and Hitzman, D. O. (1990). Microbial-enhanced waterflooding: Mink Unit project. SPE Reservoir Engineering, 5(01), 9-13.

48. Fiechter, A. (1992). Biosurfactants: moving towards industrial application. Trends in biotechnology, 10, 208-217.

49. Thomas, S. (2008). Enhanced oil recovery-an overview. Oil and Gas Science and Technology-Revue de l'IFP, 63(1), 9-19.

50. Froning, H. R., and Leach, R. O. (1967). Determination of chemical requirements and applicability of wettability alteration flooding. Journal of Petroleum Technology, 19(06), 839843.

\section{How to cite this article:}

Ishrat Jahan Badruddin, Brajesh Singh, Kritika Pandey, Ashutosh Kumar Pandey, Srinath Pandey, Ved Kumar Mishra and Prashant Ankur Jain. 2017. Application of Microbes for Recovery of Residual Crude Petroleum. Int.J.Curr.Microbiol.App.Sci. 6(8): 1229-1242. doi: https://doi.org/10.20546/ijcmas.2017.608.151 